\title{
環境庁告示による残留農薬の分析方法 (その6)（前編）
}

1984 年 6 月〜 1985 年 3 月に告示された農薬

\author{
岸部和美, 田中 稔, 田引勢 郎* \\ 環境庁水質保全局土壤農薬課 \\ *厚生省薬務局審査第一課 \\ (昭和 60 年 5 月 20 日受理)
}

\section{Analytical Methods of Pesticide Residues Based on the Notification of Environment Agency (Part 6)}

Pesticides Published in June 1984-March 1985

Kazumi Kishibe, Minoru TAnaka and Seiro TABiki*

Environment Agency, Chiyoda-ku, Tokyo 100, Japan

*Ministry of Health and Welfare, Chiyoda-ku, Tokyo 100, Japan

\section{緒言}

環境庁では農薬取締法に基づき，作物残留に係わる農 薬の登録保留基準を定めて抢り，昭和 48 年 7 月以降, 昭和 60 年 3 月までに 161 農薬について告示を行なって いる.

この登録保留基準とその分析方法についてはこれまで に本誌あるいは農薬科学に逐次紹介されているが，本稿 では後藤 ${ }^{(3)}$ ，加藤抢よび岩永 ${ }^{4)}$, 阪本扣よび大井 ${ }^{5)}$ によ り本誌に紹介されてきた解説の続編として，昭和 59 年 6 月から昭和 60 年 3 月までの間に告示された 48 農薬に ついて紹介する．表 1 と基準值拉よび告示の年月日を示 す.

\section{記載方法の解説}

記載方法は本シリーズ第 5 回 ${ }^{5)}$ の記載方法に準じてい るが，変更点もあるので以下に記す。

1）記載の順序

官報に告示された順に記載している，また，農薬名お よび化学名は告示のと扬りである.

2) 前 処 理

試料の前処理については, 昭和 59 年 12 月 20 日の告示 で一部変更された。すなわち, 従来, 試料は検体をその
まま粉䂶するか，あるいは，蒸留水を加えてホモジェネ ートすることにより調製することとされていたが（昭和 48 年 7 月 24 日告示), グアザチン等従来の方法では試料 の調製中に分解してしまうものについては，個別の分析 法に打いて特別な試料調製法を指定することができるこ ととされた。蛇足ながら，個別分析法に执いてとくに試 料調製法について指定がない場合については，従来の方 法(昭和 48 年 7 月 24 日告示. 前述)により試料を調製す るものとする. 詳しくは各論を参照されたい.

3）試料からの抽出

抽出方法としては, 1 回の分析に使用する試料の量拉 よび抽出溶媒の種類と量を記載した。通常は，試料に溶 媒を加光, 30 分間激しく振とうしたのちろ過助剤（七 ライト 545 またはハイフロスーパーセル) を敷いたろ 紙で吸引ろ過し，ろ過残渣について同様の抽出操作を繰 り返正。

また，米，麦・雑穀，豆類，まっ茶については，2 倍 量の水を加え 2 時間放置したのちに抽出溶媒を加え 30 分間激しく振とうする。これは，これら水分含量の少な い試料では，そのまま抽出した場合と含水させて抽出し た場合とで農薬の種類によっては抽出効率が著しく異な り，含水させたほうが効率がよいことが明らかとなった ためである. 
表 1 環境庁告示による残留基準（59.6.20～60.3.27）

\begin{tabular}{|c|c|c|c|c|c|c|c|c|c|c|}
\hline & \multirow{2}{*}{ 農 } & \multirow{2}{*}{$\begin{array}{l}\text { 告 示 } \\
\text { 年月日 }\end{array}$} & \multicolumn{3}{|r|}{ 残 } & 留 & \multirow{2}{*}{$\frac{\text { 基 }}{\text { 類 }^{-}}$} & \multirow[b]{2}{*}{ 豆類 } & \multicolumn{2}{|c|}{ (ppm) } \\
\hline & & & 米 & $\begin{array}{l}\text { 麦· } \\
\text { 雑穀 } \\
\end{array}$ & 果実 & 野菜 & & & 茶 & その他 \\
\hline （虫） & プロポキスル (PHC) & $\begin{array}{l}59 \cdot 6 \cdot 20 \\
\text { (一部改正) }\end{array}$ & 1 & 0.5 & 1 & 2 & 0.5 & & & \\
\hline （草） & ジウロン(DCMU) & " & 0.05 & 0.05 & 0.05 & 0.05 & 0.05 & 0.05 & 1 & さとうきび 0.05 \\
\hline （虫） & $\mathrm{XMC}$ & " & 0.2 & 0.2 & 0.2 & & & & 10 & \\
\hline （草） & アロキシジムナトリウム & " & & & 1 & 1 & 1 & 1 & & てんさい 1 \\
\hline （菌） & ジネブ & $59 \cdot 6 \cdot 20$ & & & 0.5 & 0.4 & 0.2 & & & $\begin{array}{l}\text { なつみかんの外果皮 } 10 \\
\text { きゅうりおよびとまと2 }\end{array}$ \\
\hline （菌） & マンネブ & " & & & 0.5 & 0.4 & 0.2 & 0.1 & & $\begin{array}{l}\text { なつみかんの外果皮 } 10 \\
\text { きゅうりおよびとまと2 }\end{array}$ \\
\hline （草） & フェンメディファム & " & & & & & & & & てんさい 0.05 \\
\hline （虫） & エチオフェンカルブ & $" \prime$ & & & 5 & 5 & 1 & 1 & & \\
\hline (虫, & ホスメット (PMP) & $\begin{array}{l}59.10 .31 \\
\text { (一部改正) }\end{array}$ & 0.1 & & 0.1 & 1 & & 0.05 & 0.5 & なつみかんの外果皮 2 \\
\hline (草) & プロパニル $(\mathrm{DCPA})$ & " & 0.1 & & 0.1 & 0.1 & 0.1 & & & \\
\hline （虫） & $\mathrm{BPMC}$ & " & 0.3 & 0.3 & 0.3 & 0.3 & & & 0.3 & さとらきび 0.3 \\
\hline （虫） & イソキサチオン & " & 0.05 & 0.02 & 0.2 & 0.1 & 0.05 & 0.01 & 5 & さとらきび 0.05 \\
\hline （菌） & オキシン銅 & " & & 0.1 & 2 & 1 & 0.1 & & & $\begin{array}{l}\text { なつみかんの外果皮 } 5 \\
\text { ホップ } 10\end{array}$ \\
\hline （菌） & イプロジオン & " & 3 & & 10 & 5 & 0.1 & 0.2 & & てんさい 1 \\
\hline （草） & ジノセブ (DNBP) & 59.10 .31 & & & & & & 0.05 & & \\
\hline （草） & $\mathrm{ACN}$ & " & 0.03 & & & 0.03 & & & & \\
\hline （調） & ベンジルアミノプリン & " & 0.1 & & 0.1 & 0.1 & & & & \\
\hline (ダニ) & シヘキサチン & " & & & 1 & & & & 2 & $\begin{array}{l}\text { 日本なしおよびりんご } \\
\text { を除く }\end{array}$ \\
\hline （菌） & トリアジメホン & " & & 0.5 & 0.5 & 0.5 & 0.2 & & & さとうきび 0.5 \\
\hline （草） & ペンディメタリン & " & & 0.2 & & 0.2 & 0.2 & 0.2 & & \\
\hline （菌） & ホセチル & " & & & 50 & 100 & & & & \\
\hline （虫） & フェンバレレート & " & & & 1 & 0.5 & & 0.1 & & $\begin{array}{l}\text { なつみかんの外果皮 } 20 \\
\text { てんさい } 0.5\end{array}$ \\
\hline （虫） & カルボスルファン & $\begin{array}{l}59 \cdot 10 \cdot 31 \\
59 \cdot 12 \cdot 20\end{array}$ & 0.2 & & 0.2 & 1 & 1 & & & $\begin{array}{l}\text { Wちご } 5 \text {, さとうきび } \\
0.2\end{array}$ \\
\hline （虫） & プロチオホス & $59 \cdot 10 \cdot 31$ & & & 0.1 & 0.1 & 0.05 & 0.05 & 5 & $\begin{array}{l}\text { なんかん } \\
\text { てんさい } 0.5 \\
\text { さとうきび } 0.5\end{array}$ \\
\hline (ダニ) & ジコホル(ケルセン) & $" 1$ & & & 3 & 2 & & & & なつみかんを除く \\
\hline$\left(\frac{\text { 虫, }}{\text { ダニ }}\right)$ & ダイアジノン & " & & 0.1 & & 0.1 & & & & さとらきび 0.1 \\
\hline (ダ=) & 酸化フェンブタスズ & (一部改正) & & & 2 & 2 & & & 10 & \\
\hline (虫, & オキサミル & " & & & 0.5 & 1 & 0.1 & & & \\
\hline （菌） & グアザチン & 59.12 .20 & & & 0.1 & 0.1 & & & & \\
\hline （菌） & トリホリン & " & & & 2 & 2 & & & & \\
\hline （調） & クロルメコート & " & & 5 & & & & & & \\
\hline （虫） & ブプロフェジン & " & 0.3 & 0.3 & 0.3 & 1 & & & 5 & なつみかんの外果皮 2 \\
\hline （菌） & トリシクラゾール & $60 \cdot 2 \cdot 16$ & 2 & & & & & & & \\
\hline （菌） & $\begin{array}{l}\text { ノニルフェノール } \\
\text { スルホン酸銅 }\end{array}$ & " & & & 5 & 10 & 5 & & & \\
\hline (虫, & エトリムホス & " & & & 0.2 & 0.2 & & & & \\
\hline （虫） & ベンダイオカルブ & $" \prime$ & 0.1 & & & & & & & \\
\hline (草) & プレチラクロール & $" \prime$ & 0.1 & & & & & & & \\
\hline （菌） & $\begin{array}{l}\text { カルベンダジム } \\
\text { (カルベソダゾール) }\end{array}$ & $60.3 \cdot 27$ & & & & & & 1 & & \\
\hline
\end{tabular}


表 1 (つづき)

\begin{tabular}{|c|c|c|c|c|c|c|c|c|c|c|c|c|}
\hline & \multirow{2}{*}{ 農 } & \multirow{2}{*}{ 薬 } & \multirow{2}{*}{ 名 } & \multirow{2}{*}{$\begin{array}{l}\text { 告 示 } \\
\text { 年月旦 }\end{array}$} & \multicolumn{3}{|r|}{ 残 } & 留 & \multirow{2}{*}{$\begin{array}{l}\text { 基 } \\
\text { Wも } \\
\text { 類 }\end{array}$} & \multicolumn{3}{|c|}{ (ppm) } \\
\hline & & & & & 米 & 麦· & 果実 & 野菜 & & 豆類 & 茶 & その他 \\
\hline （菌） & \multicolumn{3}{|c|}{ プロベナゾール } & 60.3 .27 & 0.5 & & & 0.1 & & & & \\
\hline (菌) & \multicolumn{3}{|c|}{ DBEDC } & " & & & 10 & 10 & & & & いちご 20 \\
\hline （菌） & \multicolumn{3}{|c|}{$\begin{array}{l}\text { ジクロフルア }=ト ゙ \\
\text { (スルフェン酸系) }\end{array}$} & $"$ & & & 15 & 15 & & & & ホップ 5 \\
\hline （虫） & \multicolumn{3}{|c|}{ スルプロホス } & " & & & & & & & & 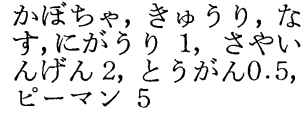 \\
\hline (草) & \multicolumn{3}{|c|}{ イソウロン } & $"$ & & & & & & & & さとうきび 0.05 \\
\hline （菌） & \multicolumn{3}{|c|}{ ピロキロン } & " & 0.2 & & & & & & & \\
\hline (菌) & \multicolumn{3}{|c|}{ フルトラニル } & " & 1 & 2 & 5 & 0.1 & 0.1 & & & \\
\hline （虫） & \multicolumn{3}{|c|}{ ペルメトリン } & " & & & 5 & 3 & 0.2 & & 20 & なつみかんの外果皮 15 \\
\hline （草） & \multicolumn{3}{|c|}{ ピラゾキシフェン } & " & 0.1 & & & & & & & \\
\hline (草) & \multicolumn{3}{|c|}{ セトキシジム } & " & & & 1 & 10 & 1 & 10 & & てんさい 0.5 \\
\hline
\end{tabular}

\section{4）液相間の分配等}

米や豆類の分析に拈いては,「ヘキサンーアセトニトリ 儿分配」を行なら場合が多い、へキサンーアセトニトリ ル分配とは, 試料をへキサン $30 \mathrm{ml}$ に溶解し,アセトニ トリル $30 \mathrm{ml}$ ずつで 2 回抽出し,アセトニトリル層を合 わせてへキサン $50 \mathrm{ml}$ で洗浄する操作のことである.

茶の分析に扔いては脱タンニンの操作を行なら場合が 多い，すなわち，熱湯浸出のろ液の $360 \mathrm{ml}$ をとり，飽 和酢酸鉛 2 4 $\mathrm{ml}$ を加光混合したのちろ過助剤を敷いた ろ紙で吸引ろ過し，ろ液を分析に供する，農薬によって はろ液に硫酸を加えてろ過することにより，過剩の酢酸 鉛を除去したのち次の操作に進む場合もある．詳しくは 官報を参照されたい。

クリーンアップの一部として「凝固液処理」を行なら 場合子多い，凝固液処理とは，適量のアセトンに溶解し た試料に凝固液 $50 \mathrm{ml}$ およびろ過助剂 $2 \mathrm{~g}$ を加兄, ゆる やかに振り混ぜ, 5 分間放置したのち吸引ろ過し, アセ トンと凝固液の混液で残椬を洗ってろ過する操作で，ろ 液を分析に供する.凝固液とは水 $400 \mathrm{ml}$ に塩化アンモ ニウム $2 \mathrm{~g}$ 抢よびリン酸 $4 \mathrm{ml}$ を加えたものである.こ の場合のアセトンの量により精製効果や回収率が異なる ので詳しくは各論を参照されたい。

5）カラムクロマトグラフィー等

カラムクロマトグラフィー(CC)については，〔〕内 に, クロマト管の内径, 固定相の種類と量, 展開溶媒の 種類と量をこの順序で記載した。展開溶媒のうちく〉 内に記したのは流出液を廃棄するフラクションである.

薄層クロマトグラフィー (TLC) については,〔】内
に，展開溶媒の種類と $R f$ の目安を記した，薄層プレー 卜の固定相は特記のない限り蛍光剂入りシリカゲル $(20$ $\mathrm{cm} \times 20 \mathrm{~cm})$ である. Rf は変動しやすいので標準品を同 時に添付して展開し確認する.

6) ガスクロマトグラフィー等

ガスクロマトグラフィー(GC)については，〔〕内に， 検出器の種類, 固定相液体の種類と濃度, カラム温度, 保持時間, 必要に応じ（）内にピークを示す成分の名 称，検出可能であるべき農薬の量，GC に供する試料溶 液の量をこの順序で記載した. 固定相液体の商品名は告 示には記載されていないので一例を示した．このものが 最適とは限らず，試料に応じて適当なものを選択する. いずれにしても GC の操作条件は各自の使用機器に応じ て最適の状態を選ぶ必要がある．窒素化合物等の定量に は，近年 Hewlett-Packard 社の「N-P FID」のような 高感度窒素・リン検出器が用いられるようになった．本 稿では N.P-FID と記載した。

高速液体クロマトグラフィー(HPLC)については[ ] 内に, 検出器の種類および（）内に測定波長, 充填剂 の種類, 溶離液の組成, 保持時間, 検出可能であるべき 農薬の量, 試料溶液の量をこの順に記載した. HPLCに ついても GC 同様機器に応じた最適条件を選ぶ.

その他操作法の詳細については官報に掲載された告示 の本文や参考書6)を参照されたい。

\section{分析 法}

(1) プロポキスル(屯たは PHC) (59.6.20 一部改正) 2-イソプロポキシフェニル N-メチルカルバマート 
検体 $20 \mathrm{~g}$ 相当の試料, アセトン $100 \mathrm{ml}+50 \mathrm{ml}$ で抽 出

$20 \mathrm{ml}$ に濃縮， $5 \%$ 塩化ナトリウム $200 \mathrm{ml}$ を加党, ジ クロロメタン $100 \mathrm{ml} \times 2$ で抽出, 脱水, 溶媒留法

残留物をアセトン $10 \mathrm{ml}$ に溶解, 凝固液処理, ジクロ ロメタン $50 \mathrm{ml} \times 2$ で抽出, 脱水, 溶媒留去, アセト ンーヘキサン (5:95) $10 \mathrm{ml}$ に溶解

$\mathrm{CC}\lceil 1.5 \mathrm{~cm} ， フ$ フッジル $10 \mathrm{~g}$ ，〈アセトンーヘキサン (5 : 95) $50 \mathrm{ml}\rangle$, アセトンーヘキサン $(15: 85) 100 \mathrm{ml}]$

GC [N.P.FID， $5 \% \mathrm{OV}-17 ， 160 \sim 180^{\circ} \mathrm{C} ， 4$ 分， 0.4 $\mathrm{ng}$ ，ヘキサン $4 \mathrm{ml}]$

(2) ジウロン (または DCMU) (59.6.20 一部改正) 3-(3,4-ジクロロフェニル)-1,1-ジメチル尿素

A 法（米，麦・雑穀，豆類）

試料 $20 \mathrm{~g} ，$ アセトン $150 \mathrm{ml}+100 \mathrm{ml}$ で抽出

$50 \mathrm{ml}$ に濃縮， $5 \%$ 塩化ナトリウム $200 \mathrm{ml}$ を加党，ジ クロロメタン $100 \mathrm{ml} \times 2$ で抽出, 脱水, 溶媒留去 $\downarrow$

残留物をヘキサンーアセトニトリル分配，溶媒留去

残留物をアセトン $10 \mathrm{ml}$ に溶解, 凝固液処理, ジクロ ロメタン $50 \mathrm{ml} \times 2$ で抽出, 脱水, 溶媒留去, アセ卜 ソーヘキサン (5：95) $10 \mathrm{ml}$ に溶解

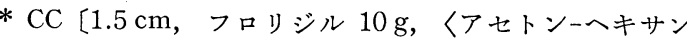
(5 : 95) $100 \mathrm{ml}\rangle$, アセトンーヘキサン $(15: 85) 100 \mathrm{ml}$ ], 溶媒留去

**ベンゼン $0.5 \mathrm{ml}$ に溶解， ジメチルスルホキシド 0.5 $\mathrm{ml}$, 水素化ナトリウム約 $0.2 \mathrm{~g}$ およびヨウ化メチル $0.5 \mathrm{ml}$ を加え, $25^{\circ} \mathrm{C}$ で 30 分間放置

ヘキサン $3 \mathrm{ml}$ を加え振とら, 蒸留水 $10 \mathrm{ml}$ を徐々に 加え, 振とら後上層の有機溶媒層 $4 \mathrm{ml}$ を分取

GC [N.P.FID , 5\% OV-17, $180 \sim 200^{\circ} \mathrm{C}, 4$ 分, 0.2 $\mathrm{ng}$, 有機溶媒層 $4 \mathrm{ml}$ ]

B 法（果実，野菜，いも類，さとうきび，まっ茶） 検体 $20 \mathrm{~g}$ 相当の試料（まっ茶の場合は $4 \mathrm{~g}$ )，アセト ソ $100 \mathrm{ml}+50 \mathrm{ml}$ で抽出

$20 \mathrm{ml}$ に濃縮， $5 \%$ 塩化ナトリウム $200 \mathrm{ml}$ を加光，ジ クロロメタン $100 \mathrm{ml} \times 2$ で抽出, 脱水, 溶媒留去

残留物をアセトン $10 \mathrm{ml}$ に溶解, 凝固液処理, ジクロ ロメタン（まっ茶の場合, エチルエーテルーヘキサン (1: 1)) $50 \mathrm{ml} \times 2$ で抽出, 脱水, 溶媒留去
アセトンーヘキサン (5:95) $10 \mathrm{ml}$ に溶解したのち， A 法の*以下の操作を行なう.

C法 (茶 (まっ茶を除く)

試料 $9 \mathrm{~g}, 100^{\circ} \mathrm{C}$ の水 $540 \mathrm{ml}$ で抽出

$360 \mathrm{ml}$ を分取, 飽和酢酸鉛溶液 $2 \mathrm{ml}$ を加兄, 万過, 蒸留水-アセトン (1:1) $50 \mathrm{ml}$ で洗浄 $\downarrow$

エチルェーテルーヘキサン (1:1) $100 \mathrm{ml} \times 2$ で抽出, 脱水，溶媒留去

アセトンーヘキサン(5: 95) $10 \mathrm{ml}$ に溶解したのち，A 法の*以下の操作を行なう.

ジウロンをメチル化して N.P-FID.GC で定量する方 法である。

検量線はジウロン標準品の $0.2 \sim 2 \mathrm{ppm}$ アセトン溶液 $1 \mathrm{ml}$ について，**以降の操作を行なって作成する.

(3) XMC (59.6.20 一部改正)

3,5-ジメチルフェニル N-メチルカルバマート

A法（米，麦・雑穀，果実，まっ茶）

検体 $20 \mathrm{~g}$ 相当の試料（まっ茶の場合は $5 \mathrm{~g}$ ), アセト ソ $100 \mathrm{ml}+50 \mathrm{ml}$ で抽出

$20 \mathrm{ml}$ に濃縮, $5 \%$ 塩化ナトリウム $200 \mathrm{ml}$ を加え, ジ クロロメタン $100 \mathrm{ml} \times 2$ で抽出, 脱水, 溶媒留去

残留物をアセトン $10 \mathrm{ml}$ に溶解，凝固液処理，ジクロ ロメタン（まっ茶の場合はェチルェーテルーヘキサン (1:1)) $50 \mathrm{ml} \times 2$ で抽出, 脱水, 溶媒留去, アセトンー ヘキサン $(5: 95) 10 \mathrm{ml}$ に溶解

\section{$\downarrow$}

* CC [1.5 cm，フロリジル $10 \mathrm{~g}$ 〈アセトンーヘキサン (5:95) $50 \mathrm{ml}\rangle$, アセトンーヘキサン $(15: 85) 100 \mathrm{ml}]$, 溶媒留去

GC $\left[\mathrm{N} \cdot \mathrm{P}-\mathrm{FID}, 5 \% \mathrm{OV}-17,160 \sim 180^{\circ} \mathrm{C}, 4\right.$ 分, 0.4 $\mathrm{ng}$, ヘキサン $4 \mathrm{ml}]$

B法（茶（まっ茶を除く）

試料 $9 \mathrm{~g}, 100^{\circ} \mathrm{C}$ の水 $540 \mathrm{ml}$ で抽出

$360 \mathrm{ml}$ を分取，飽和酢酸鉛溶液 $2 \mathrm{ml}$ を加光， 万過， 蒸留水一アセトン $(1: 1) 50 \mathrm{ml}$ で洗浄

エチルエーテルーヘキサン (1:1) $100 \mathrm{ml} \times 2$ で抽出, 脱水, 溶媒留去

アセトンーヘキサン (5:95) $10 \mathrm{ml}$ に溶解したのち, A 法の*以下の操作を行なう.

(4) アロキシジムナトリウム（59.6.20 一部改正）

2-(1-アリルオキシアミノブチリデン)-5,5-ジメチル4-メトキシカルボニルシクロヘキサンー1,3-ジオン陰イ オンのナトリウム塩 
検体 $20 \mathrm{~g}$ 相当の試料,アセトン $100 \mathrm{ml}+50 \mathrm{ml}$ で抽出 $\downarrow$

$50 \mathrm{ml}$ に濃縮, $5 \%$ 塩化ナトリウム $200 \mathrm{ml}$ 和よび塩酸 $3 \mathrm{ml}$ を加え, ヘキサン $100 \mathrm{ml} \times 2$ で抽出

$50 \mathrm{ml}$ に濃縮, $5 \%$ 塩化ナトリウム含有 $0.1 \mathrm{~N}$ 水酸化 ナトリウム溶液 $50 \mathrm{ml} \times 2$ で抽出

水層をへキサン $50 \mathrm{ml}$ で洗浄, $6 \mathrm{~N}$ 塩酸で $\mathrm{pH} 1$ ～2 に 調整, ヘキサン $50 \mathrm{ml} \times 2$ で抽出, 脱水, 溶媒留去, ア セトン $0.5 \mathrm{ml}$ に溶解

TLC〔シリカゲル，アセトンーヘキサン $\quad(2: 8), \quad R f$ $0.3 \sim 0.4]$

ジクロロメタン $30 \mathrm{ml} \times 2$ でシリカゲルより抽出, 溶 媒留去

HPLC 〔紫外分光光度計 $(254 \mathrm{~nm}$ なたは $280 \mathrm{~nm})$, シ リカ ODS, 水ーアセト ニトリルー酢酸 $(30: 70: 1), 4 \sim$ 5 分, $10 \mathrm{ng}$, アセトニトリル $2 \mathrm{ml}]$

(5) ジネブおよびマンネブ (59.6.20)

エチレンビス（ジチオカルバミド酸）亜鉛

エチレンビス（ジチオカルバミド酸）マンガン

検体 $100 \mathrm{~g}$ 相当の試料（豆類の場合は $50 \mathrm{~g}$ ，なつみか んの外果皮の場合は検体 $10 \mathrm{~g}$ 相当の試料）を分解フ ラスコにはかりとり,塩化第一スズ $5 \mathrm{~g}$ を加え, 沸騰さ せた直後の $1.5 \mathrm{~N}$ 塩酸 $200 \mathrm{ml}$ を加之， 45 分間加熱反 応（第一吸収管 $6.5 \%$ 水酸化ナトリウム溶液 $15 \mathrm{ml}$, 第二吸収管 硫酸 $15 \mathrm{ml}$ ，第三吸収管 エタノール 10 $\mathrm{ml}$ ，流速 30 60 ml/分) (図 1)

$\downarrow$

GC〔FPD(S)，ポーラスポリマー(TENAX-GC 等), $120 \sim 140^{\circ} \mathrm{C}, 3$ 分, $0.4 \mathrm{ng}$, エタノール $10 \mathrm{ml}$ (第三吸 収管)]

ジネブ，マンネブを酸分解して，生成する二硫化炭素 を冷却したエタノールに吸収させ，FPD・GC により 定量する方法である，検量線は，二硫化炭素の標準品 を用いて作成する．検量線より二硫化炭素の重量を求 め, ジネブの場合には係数 1.81 , マンネブの場合に

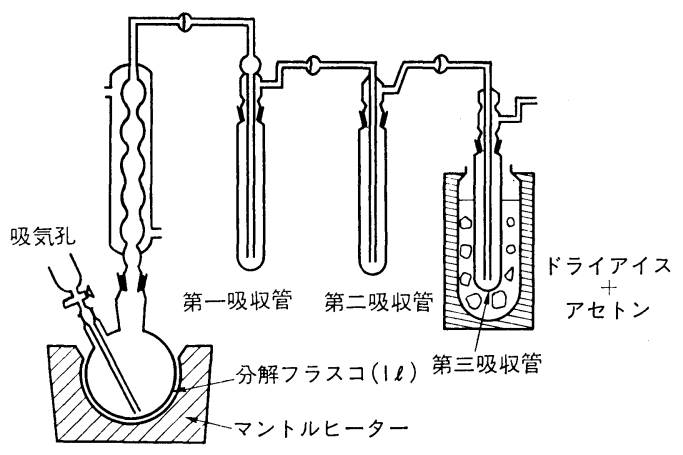

図 1 分解吸収装置の一例
は係数 1.74 を乗じてジネブ，マンネブの重量を求め る.

(6) フェンメディファム $(56.6 .20)$

メチル 3-(3-メチルカルバニロイルキシ)カルバニラ - ト

検体 $50 \mathrm{~g}$ 相当の試料, アセトン $150 \mathrm{ml}+100 \mathrm{ml}$ で 抽出

$50 \mathrm{ml}$ に濃縮， $5 \%$ 塩化ナトリウム $200 \mathrm{ml}$ を加え, ジ クロロメタン $100 \mathrm{ml} \times 2$ で抽出， $1 \mathrm{~N}$ 塩酸 $100 \mathrm{ml}$ で 洗浄, 脱水, 溶媒留去

残留物を $2 \mathrm{~N}$ 水酸化カリウム溶液 $200 \mathrm{ml}$ に溶解，消 泡シリコン $1 \mathrm{ml}$ を加光水蒸気蒸留を行なう. 受器 (1 $\mathrm{N}$ 硫酸 $25 \mathrm{ml}$ ), 留出液 $100 \mathrm{ml}$

留出液をジクロロメタン $50 \mathrm{ml}$ で洗浄, $4 \mathrm{~N}$ 水酸化ナ トリウム液 $10 \mathrm{ml}$ を加え，ジクロロメタン $50 \mathrm{ml} \times 2$ で抽出, 脱水, $2 \%$ クロロアセチルクロリドベンゼン 溶液 $1 \mathrm{ml}$ を加光, 溶媒留去

$\mathrm{GC}\left[\mathrm{ECD}, \quad 5 \sim 10 \% \mathrm{SE}-30,180 \sim 200^{\circ} \mathrm{C}, 4 \sim 5\right.$ 分, $0.04 \mathrm{ng}$ ，ヘキサン $40 \mathrm{ml}]$

加水分解によって生成する, $m$-トルイジンをクロロア セチル化して GC で定量する方法である．検量線は， m-トルイジン標準品を $2 \%$ クロロアセチルクロリド ベンゼン溶液で，クロロアセチル化して作成する．検 量線より $m$-トルイジンの重量を求め, 係数 2.81 を 乗じてフェンメディファムの重量を求める.

(7) エチオフェンカルブ (59.6.20)

2-(エチルチオメチル)フェニル N-メチルカルバマー 卜

検体 $20 \mathrm{~g}$ 相当の試料, アセトン $100 \mathrm{ml}+50 \mathrm{ml}$ で抽 出

$20 \mathrm{ml}$ に濃縮， $5 \%$ 塩化ナトリウム $200 \mathrm{ml}$ を加え, ジ クロロメタン $100 \mathrm{ml} \times 2$ で抽出, 脱水, 溶媒留去 $\downarrow$

残留物をアセトン $40 \mathrm{ml}$ に溶解, 凝固液処理, ジクロ ロメタン $50 \mathrm{ml} \times 2$ で抽出, 脱水, 溶媒留去, アセ卜 ソ $2 \mathrm{ml}$ に溶解

* $20 \%$ 硫酸マグネシウム溶液 $5 \mathrm{ml}$ および $1.6 \%$ 過マン ガン酸カリウム溶液 $20 \mathrm{ml}$ を加光, 30 分間放置後, ジクロロメタン $50 \mathrm{ml} \times 2$ で抽出, 脱水, 溶媒留去 $\downarrow$

アセトン $1.6 \mathrm{ml}$ に溶解， $N, O$-ビス(トリメチルシリ ル)トリフルオロアセトアミド $0.4 \mathrm{ml}$ を加え, 約 16 時間暗所に放置後，ヘキサン $2 \mathrm{ml}$ を加える.

$\mathrm{GC}\left[\mathrm{FPD}(\mathrm{S}), 5 \% \mathrm{OV}-101,220 \sim 240^{\circ} \mathrm{C}, 4\right.$ 分, 2 $\mathrm{ng}$, 有機溶媒 $4 \mathrm{ml}$ ] 
エチオフェンカルブを酸化してスルホンとし，トリメ チルシリル化したのち，FPD・GC により定量する方 法である。

検量線は, エチオフェンカルブの標準品の 1 1 $10 \mathrm{ppm}$ アセトン溶液 $2 \mathrm{ml}$ について, * 以降の操作を行なっ て作成する.

(8) ホスメット (または PMP) (59.10.31 一部改正) $O, O$-ジメチル S-フタルイミドメチルジチオホスフェ - ト

\section{A法 (米, 豆類)}

試料 $50 \mathrm{~g}$ ，アセトン $150 \mathrm{ml}+100 \mathrm{ml}$ で抽出

$$
\downarrow
$$

$100 \mathrm{ml}$ に濃縮， $5 \%$ 塩化ナトリウム $200 \mathrm{ml}$ を加え， ヘキサン $100 \mathrm{ml} \times 2$ で抽出, 脱水, $2 \%$ ジェチレング リコールアセトン溶液 $0.1 \mathrm{ml}$ を加え, 溶媒留去

残留物をへキサンーアセトニトリル分配， $2 \%$ ジェレレ ングリコールアセトン溶液 $0.1 \mathrm{ml}$ を加え溶媒留去, 残留物をアセトンーヘキサン (5: 95) $10 \mathrm{ml}$ に溶解

$$
\downarrow
$$

* CC $[1.5 \mathrm{~cm}$ ，フロリジル $10 \mathrm{~g}$ 〈アセトンーヘキサン (5:95) $100 \mathrm{ml}\rangle$, アセトンーヘキサン (15:85) 50 $\mathrm{ml}$ ], $2 \%$ ジェチレングリコールアセトン溶液 $0.1 \mathrm{ml}$ を加党, 溶媒留去

GC $\left[\mathrm{FTD}, \mathrm{FPD}(\mathrm{P}), 5 \% \mathrm{OV}-210,210 \sim 230^{\circ} \mathrm{C}, 3 \sim\right.$ 4 分, $1 \mathrm{ng}$, アセトン $2 \mathrm{ml}]$

B 法（果実，野菜，まっ茶）

検体 $50 \mathrm{~g}$ 相当の試料（なつみかんの外果皮およびま っ茶の場合は $5 \mathrm{~g}$ ), アセトン $150 \mathrm{ml}+100 \mathrm{ml}$ で抽 出

$50 \mathrm{ml}$ に濃縮, $5 \%$ 塩化ナトリウム $200 \mathrm{ml}$ を加え, 一 キサン $100 \mathrm{ml} \times 2$ で抽出, 脱水, $2 \%$ ジェチレングリ コールアセトン溶液 $0.1 \mathrm{ml}$ を加え, 溶媒留去 $\downarrow$

残留物をアセトンーヘキサン (5: 95) $10 \mathrm{ml}$ に溶解した のち，A法の*以下の操作を行なら.

C法（茶（まっ茶を除く））

試料 $9 \mathrm{~g}, 100^{\circ} \mathrm{C}$ の水 $540 \mathrm{ml}$ で抽出

$360 \mathrm{ml}$ を分取, 飽和酢酸鉛溶液 $2 \mathrm{ml}$ を加光, ろ過, 蒸留水-アセトン (1:1) $50 \mathrm{ml}$ で洗浄

\section{$\downarrow$}

エチルエーテルーヘキサン (1: 1) $100 \mathrm{ml} \times 2$ で抽出,

脱水, $2 \%$ ジェチレングリコールアセトン溶液 $0.1 \mathrm{ml}$ を加光, 溶媒留去

残留物をアセトンーヘキサン (5:95) $10 \mathrm{ml}$ に溶解した のち, A法の*以下の操作を行なう.

(9) プロパニル(または DCPA) (59.10.31 一部改正) 3,4-ジクロロプロピオンアニリド
A法 (米)

試料 $20 \mathrm{~g}$ ，アセトン $150 \mathrm{ml}+100 \mathrm{ml}$ で抽出

$50 \mathrm{ml}$ に濃縮, $5 \%$ 塩化ナトリウム $200 \mathrm{ml}$ を加え, 一 キサン $100 \mathrm{ml} \times 2$ で抽出, 脱水, 溶媒留去

残留物をへキサンーアセトニトリル分配, 溶媒留去, 残留物をアセトンーヘキサン (5：95) $10 \mathrm{ml}$ に溶解

\section{$\downarrow$}

* CC [1.5 cm，フロリジル $10 \mathrm{~g}$ 〈アセトンーヘキサン (5:95) $100 \mathrm{ml}\rangle$, アセトンーヘキサン (15:85) $100 \mathrm{ml}$ ], 溶媒留去, 残留物をアセトン $0.5 \mathrm{ml}$ に溶解

* TLC〔シリカゲル, メタノールークロロホルム(1:50), Rf 0.5$]$

アセトン $30 \mathrm{ml} \times 2$ でシリカゲルより抽出, 溶媒留去 $\downarrow$

$\mathrm{GC} 〔 \mathrm{ECD}, 5 \%$ PEG $20 \mathrm{~m}, 200 \sim 220^{\circ} \mathrm{C}, 6$ 分, 0.2 $\mathrm{ng}$, ヘキサン $4 \mathrm{ml}]$

B法（果実，野菜，いも類）

検体 $20 \mathrm{~g}$ 相当の試料, アセトン $100 \mathrm{ml}+50 \mathrm{ml}$ で抽 出

$20 \mathrm{ml}$ に濃縮, $5 \%$ 塩化ナトリウム $200 \mathrm{ml}$ を加え, 一 キサン $100 \mathrm{ml} \times 2$ で抽出, 脱水, 溶媒留去

$$
\downarrow
$$

残留物をアセトンーヘキサン (5: 95) $10 \mathrm{ml}$ に溶解した のち, A法の*以下の操作を行なう.

(10) BPMC (59.10.31 一部改正)

2-sec-ブチルフェニル N-メチルカルバマート

$\mathrm{A}$ 法（米, 麦·雑穀, 果実, 野菜, さとうきび, まっ茶) 検体 $20 \mathrm{~g}$ 相当の試料 (まっ茶の場合は $5 \mathrm{~g}$ ), アセト ン $150 \mathrm{ml}+100 \mathrm{ml}$ で抽出

$40 \mathrm{ml}$ に濃縮, $5 \%$ 塩化ナトリウム $200 \mathrm{ml}$ を加え, ジ クロロメタン $100 \mathrm{ml} \times 2$ で抽出, 脱水, 溶媒留去

$$
\downarrow
$$

残留物をアセトン $10 \mathrm{ml}$ に溶解, 凝固液処理, ジクロ ロメタン（まっ茶の場合，エチルエーテルーヘキサン (1:1)) $50 \mathrm{ml} \times 2$ で抽出, 脱水, 溶媒留去, アセトンー ヘキサン (5:95) $10 \mathrm{ml}$ に溶解

* CC〔1.5 cm, フロリジル $10 \mathrm{~g}$ 〈アセトンーヘキサン (5:95) $50 \mathrm{ml}\rangle$, アセトンーヘキサン (15:85) $100 \mathrm{ml}$ ], 溶媒留去

GC〔FTD または N.P-FID, $5 \%$ OV-3, 160〜180 ${ }^{\circ} \mathrm{C}, 3 \sim 4$ 分, $0.4 \mathrm{ng}$, ヘキサン $4 \mathrm{ml}$ ]

B法（茶（まっ茶を除く）） 試料 $9 \mathrm{~g}, 100^{\circ} \mathrm{C}$ の水 $540 \mathrm{ml}$ で抽出 
$360 \mathrm{ml}$ を分取, 飽和酢酸鉛溶液 $2 \mathrm{ml}$ を加え, ろ過, 蒸留水-アセトン (1:1) $50 \mathrm{ml}$ で洗浄

エチルエーテルーヘキサン (1:1) $100 \mathrm{ml} \times 2$ で抽出, 脱水, 溶媒留去

アセトンーヘキサン $(5: 95) 10 \mathrm{ml}$ に溶解したのち, A 法の*以下の操作を行なら.

(11) イソキサチオン (59.10.31 一部改正)

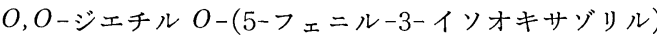
ホスホロチオアート

A法（米，麦・雑穀，豆類）

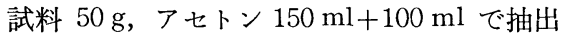
$\downarrow$

$100 \mathrm{ml}$ に濃縮， $5 \%$ 塩化ナトリウム $200 \mathrm{ml}$ を加觉， ヘキサン $100 \mathrm{ml} \times 2$ で抽出，脱水，溶媒留去 $\downarrow$

残留物をへキサンーアセトニトリル分配, 溶媒留去, 残留物をエチルエーテルーヘキサン (15:85) $10 \mathrm{ml}$ に 溶解

* CC [1.5 cm, フロリジル $10 \mathrm{~g}$,〈エチルエーテルヘキサン (15:85) $100 \mathrm{ml}\rangle$, エチルエーテルーヘキサン (30:70) $100 \mathrm{ml}$ ], 溶媒留去

$\mathrm{GC}[\mathrm{FTD}, \mathrm{FPD}(\mathrm{P}), 5 \%$ シリコン系液層（またはウ ルトラボンド $20 \mathrm{M}), 210 \sim 230^{\circ} \mathrm{C}, 3 \sim 4$ 分, $1 \mathrm{ng}$, ア セトン $2 \mathrm{ml}$ ]

$\mathrm{B}$ 法 (果実, 野菜，いも類，まっ茶，さとうきび)

検体 $50 \mathrm{~g}$ 相当の試料（まっ茶の場合は試料 $5 \mathrm{~g}$ ), ア セトン $150 \mathrm{ml}+100 \mathrm{ml}$ で抽出

$$
\downarrow
$$

$50 \mathrm{ml}$ に濃縮, $5 \%$ 塩化ナトリウム $200 \mathrm{ml}$ を加え, へ キサン $100 \mathrm{ml} \times 2$ で抽出, 脱水, 溶媒留去

残留物をエチルエーテル-ヘキサン (15:85) $10 \mathrm{ml}$ に 溶解したのち, A法の*以下の操作を行なう.

C法 (茶 (まっ茶を除く)

試料 $9 \mathrm{~g}, 100^{\circ} \mathrm{C}$ の水 $540 \mathrm{ml}$ で抽出

$360 \mathrm{ml}$ を分取, 飽和酢酸鉛溶液 $2 \mathrm{ml}$ を加え, 万過, 蒸留水-アセトン (1:1) $50 \mathrm{ml}$ で洗浄

ヘキサン $100 \mathrm{ml} \times 2$ で抽出, 脱水, 溶媒留去

$$
\downarrow
$$

残留物をエチルエーテルーヘキサン (15: 85) $10 \mathrm{ml}$ に 溶解したのち, A法の*以下の操作を行なう.

(12) オキシン銅 (59.10.31 一部改正)

ビス(8-キノリノラト)銅（II）

検体 $50 \mathrm{~g}$ 相当の試料 (ホップの場合は $5 \mathrm{~g}$ ), $1 \mathrm{~N}$ 塩 酸 $5 \mathrm{ml}$ を加学, アセトン $150 \mathrm{ml}+100 \mathrm{ml}$ で抽出, 1 \%硫酸銅溶液 $0.5 \mathrm{ml}$ を加え，アセトンを留去

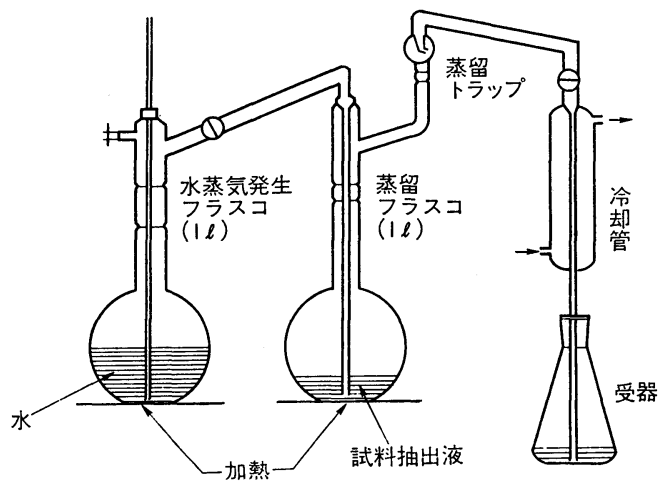

図 2 水蒸気蒸留装置の一例

\section{$\downarrow$}

蒸留水 $100 \mathrm{ml}$ で $1 l$ の蒸留フラスコに移す. エチレ ンジアミン四酢酸二ナトリウム $50 \mathrm{~g}$ および無水炭酸 ナトリウム $6 \mathrm{~g}$ を加え, 水蒸気蒸留（図 2 ）を行なう. 受器 ( $1 \mathrm{~N}$ 塩酸 $20 \mathrm{ml}$ および $1 \%$ 硫酸銅溶液 $0.5 \mathrm{ml})$, 留出液 $200 \mathrm{ml}$

塩化ナトリウム $60 \mathrm{~g}$ を加え, ジクロロメタン $100 \mathrm{ml}$ で洗浄， $1 \mathrm{~N}$ 水酸化ナトリウム溶液を加えて $\mathrm{pH} 7$ 8 に調整, ジクロロメタン $100 \mathrm{ml} \times 2$ で抽出, 脱水, 溶媒留去

HPLC〔蛍光光度型検出器 (励起波長 $380 \mathrm{~nm}$, 蛍光波 長 $520 \mathrm{~nm})$, 多孔性スチレンジビニルベンゼン共重合 体等の HPLC 用ゲル，1\%硝酸アルミニウムーメタ， ール溶液, 3〜4 分, $10 \mathrm{ng}]$

(13) イプロジオン (59.10.31 一部改正)

N-イソプロピル-3-(3,5-ジクロロフェニル)-2,4-ジ オキソイミダゾリジン-1-カルボキサミド

A 法 (米, 豆類)

試料 $20 \mathrm{~g}$ ，アセトン $100 \mathrm{ml}+50 \mathrm{ml}$ で抽出

$$
\downarrow
$$

$50 \mathrm{ml}$ に濃縮, $5 \%$ 塩化ナトリウム $200 \mathrm{ml}$ を加光, 、 キサン $100 \mathrm{ml} \times 2$ で抽出, 脱水, 溶媒留去

残留物をへキサンーアセトニトリル分配, 溶媒留去, エチルエーテルーヘキサン (1: 1) $5 \mathrm{ml}$ に溶解

* CC〔1.5 cm, フロリジル $10 \mathrm{~g}$,〈ェチルェーテルーヘ キサン (1:1) $100 \mathrm{ml}$, アセトンーヘキサン (15:85) $100 \mathrm{ml}$ ], 溶媒留去

GC [FTD, N.P-FID, $5 \% \mathrm{OV}-1,190 \sim 220^{\circ} \mathrm{C}, 3 \sim$ 4 分, $0.4 \mathrm{ng}$ (イプロジオン), $4 \sim 5$ 分, $0.8 \mathrm{ng}$ (イプ ロジオン代謝物) **，アセトン $4 \mathrm{ml}$ ]

B法 (果実, 野菜, いも類, てんさい)

検体 $20 \mathrm{~g}$ 相当の試料, アセトン $100 \mathrm{ml}+50 \mathrm{ml}$ で抽 出 


\section{$\downarrow$}

$20 \mathrm{ml}$ に濃縮, $5 \%$ 塩化ナトリウム $200 \mathrm{ml}$ を加え, へ キサン $100 \mathrm{ml} \times 2$ で抽出, 脱水, 溶媒留去

エチルエーテルーヘキサン (1:1) $5 \mathrm{ml}$ に溶解したの ち, A法の*以下の操作を行なう。

イプロジオンおよびその代謝物を $\mathrm{GC}$ 上で分離定量し てその合量をイプロジオン残留量とする，検量線は, それぞれの標準品を用いて作成する，代謝物からイプ ロジオンへの換算係数は, 1 である.

*** $N$ - (2, 5-ジクロロフェニル)-3-イソプロピル-2, 4-ジ オキソイミダゾリジン-1-カルボキサミド

(14) ジノセブのアルカノールアミン塩(または DNBP のアルカノールアミン塩) (59.10.31)

2-sec-ブチル-4,6-ジニトロフェノールのアルカノー ルアミン塩

試料 $20 \mathrm{~g}, 6 \mathrm{~N}$ 塩酸 $5 \mathrm{ml}$ を加え，アセトン $150 \mathrm{ml}+$ $100 \mathrm{ml}$ で抽出

$50 \mathrm{ml}$ に濃縮, $5 \%$ 塩化ナトリウム $200 \mathrm{ml}$ を加え, 一 キサン $100 \mathrm{ml} \times 2$ で抽出, 脱水, 溶媒留去

残留物をヘキサンーアセトニトリル分配, 溶媒留去 $\downarrow$

残留物をエチルエーテル $30 \mathrm{ml}$ に溶かしてメチル化装 置（図 3 ） の反応管に移す. 酢酸 1 滴を加党，ジアゾ メタンが過唾になり微黄色を呈するまでジアゾメタン を通じる。 $25 \sim 30^{\circ} \mathrm{C} て ゙ 30$ 分間放置したのち, 溶媒 留去, エチルエーテルーヘキサン (3:7) $10 \mathrm{ml}$ に溶解 $\downarrow$

$\mathrm{CC}[1.5 \mathrm{~cm}$ ，フロリジル $10 \mathrm{~g}$,〈ェチルェーテルーヘ キサン (3:7) $50 \mathrm{ml}\rangle$, アセトンーヘキサン (5:95) 50 $\mathrm{ml}$ ], 溶媒留去

$\mathrm{GC}\left[\mathrm{ECD}, 5 \% \mathrm{OV}-17,200 \sim 220^{\circ} \mathrm{C}, 4\right.$ 分, $0.02 \mathrm{ng}$, ヘキサン $10 \mathrm{ml}]$

ジノセブをジアゾメタンによりメチル化し ECD.GC で定量する方法である．検量線は，ジノセブ標準品の $100 \mathrm{ppm}$ アセトン溶液 $2 \mathrm{ml}$ をジアゾメタンでメチル 化し, ヘキサンで希釈, $0.005 \sim 0.1 \mathrm{ppm}$ 溶液とした ものを用いて作成する.

(15) $\mathbf{A C N}(59.10 .31)$

2-アミノ-3-クロロ-1,4-ナフトキノン

A法（米)

試料 $20 \mathrm{~g}$, アセトン $150 \mathrm{ml}+100 \mathrm{ml}$ で抽出, $50 \mathrm{ml}$ に 濃縮

* $5 \%$ 塩化ナトリウム $200 \mathrm{ml}$ を加光, ジクロロメタン $100 \mathrm{ml} \times 2$ で抽出, 脱水, 溶媒留去

$\downarrow$

残留物をヘキサンーアセトニトリル分配, 溶媒留去

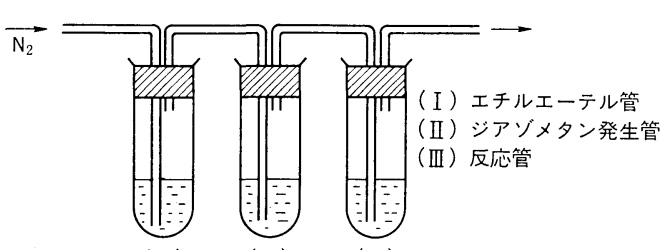

( I )

(II)

(III)

図 3 メチル化装置の一例

アセトン $5 \mathrm{ml}$ に溶解, 凝固液処理, ジクロロメタン $50 \mathrm{ml} \times 2$ で抽出, 脱水, 溶媒留去, アセトンーヘキサ ン (5: 95) $10 \mathrm{ml}$ に溶解

\section{$\downarrow$}

$\mathrm{CC}\lceil 1.5 \mathrm{~cm}$, フロリジル $10 \mathrm{~g}$ 〈アセトンーヘキサン (5: 95) $50 \mathrm{ml}\rangle$, アセトンーヘキサン $(15: 85) 50 \mathrm{ml}$ ], 溶媒留去

\section{$\downarrow$}

$\mathrm{GC}\left[\mathrm{ECD}, 5 \% \mathrm{OV}-210,180 \sim 200^{\circ} \mathrm{C}, 4\right.$ 分, $0.04 \mathrm{ng}$, ヘキサン $10 \mathrm{ml}]$

$\mathrm{B}$ 法 (野菜)

検体 $20 \mathrm{~g}$ 相当の試料, アセトン $100 \mathrm{ml}+50 \mathrm{ml}$ で抽 出

$\downarrow$

$20 \mathrm{ml}$ に濃縮したのち，A法の*以下の操作を行なら.

(16) 6-( $\boldsymbol{N - ヘ ゙ ン シ ゙ ル ア ミ ノ ) フ ゚ リ ン ~}(59.10 .31)$

6-(N-ベンジルアミノ)プリン

検体 $20 \mathrm{~g}$ 相当の試料, アセトン $150 \mathrm{ml}+100 \mathrm{ml}$ で 抽出

$50 \mathrm{ml}$ に濃縮, $5 \%$ 塩化ナトリウム $200 \mathrm{ml}$ を加え, 一 キサン $100 \mathrm{ml} \times 2$ で洗浄

\section{$\downarrow$}

水層に $1 \mathrm{~N}$ 水酸化ナトリウム溶液を加えて $\mathrm{pH}$ 6〜7 に調整, 酢酸エチル $100 \mathrm{ml} \times 2$ で抽出, 脱水, 溶媒留 去

アセトン $5 \mathrm{ml}$ に溶解, 凝固液処理, ヘキサン $50 \mathrm{ml}$ で洗浄, 塩化ナトリウム $30 \mathrm{~g}$ を加光, $1 \mathrm{~N}$ 水酸化ナト リウム溶液を加え, $\mathrm{pH}$ 6〜 7 に調整, 酢酸エチル 100 $\mathrm{ml} \times 2$ で抽出, 脱水, 溶媒留去

* ベンゼン $0.5 \mathrm{ml}$ に溶解, ジメチルスルホキシド 0.5 $\mathrm{ml}$, 水素化ナトリウム約 $0.2 \mathrm{~g}$, ヨウ化メチル $0.5 \mathrm{ml}$ を加え, $30^{\circ} \mathrm{C}$ で 1 時間放置

\section{$\downarrow$}

ヘキサン $5 \mathrm{ml}$ を加え振とら, 蒸留水 $10 \mathrm{ml}$ を徐々に 加古, 振とら後へキサン層を分取, 脱水, 溶媒留去, アセトンーヘキサン (15:85) $10 \mathrm{ml}$ に溶解

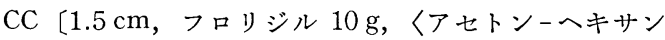
(15:85) $50 \mathrm{ml}\rangle$, アセトンーヘキサン(30:70) $50 \mathrm{ml}$ ], 溶媒留去 
GC [FTD, N.P-FID, $5 \% \mathrm{OV}-101,220 \sim 240^{\circ} \mathrm{C}$, 4 分, $0.2 \mathrm{ng}$, ヘキサン $4 \mathrm{ml}]$

6-(N-ベンジルアミノ) プリンをメチル化し， N.P. FID·GCにより定量する方法である.

検量線は6- $(N$-ベンジルアミノ) プリン標準品の0.2 $4 \mathrm{ppm}$ アセトン溶液 $1 \mathrm{ml}$ について* 以降の操作 (CC を除く）を行なって作成する。

(17) シヘキサチン $(59.10 .31)$

水酸化トリシクロヘキシルシズ

A法（果実，まっ茶）

検体 $20 \mathrm{~g}$ 相当の試料（まっ茶の場合は試料 $10 \mathrm{~g}$ ), トロポロン0.05\%を含む酢酸ーアセトンーヘキサン (1: $30: 60) 150 \mathrm{ml}$ +酢酸-ベンゼン (1:99) $100 \mathrm{ml}$ で抽出 (30 分間振とう, 毎分 2000 回転で遠心分離し上澄及部 分をろ過)

$50 \mathrm{ml}$ に濃縮, 臭化水素酸 $20 \mathrm{ml}$ を加え, 20 分間振と らしたのち，5\% 塩化ナトリウム溶液 $50 \mathrm{ml}$ を加壳， ジクロロメタン $50 \mathrm{ml} \times 2$ で抽出, 脱水, 溶媒留去

* 残留物を乾燥エチルエーテル $20 \mathrm{ml}$ に溶解, $n$-ブチル リチウム $4 \mathrm{ml}$ を加え, 密栓をして室温で 4 分間かく はんしたのち，5\% 塩化ナトリウム溶液 $50 \mathrm{ml}$ を加 え, ヘキサン $50 \mathrm{ml} \times 2$ で抽出, 脱水, 溶媒留去, 残 留物にヘキサン $10 \mathrm{ml}$ を加え溶解

$\mathrm{CC}[1.5 \mathrm{~cm}, 5 \mathrm{w} / \mathrm{w} \%$ 含水フロリジル $10 \mathrm{~g}$, ヘキサ ン $60 \mathrm{ml}$ で展開し, 初めの溶出液 $20 \mathrm{ml}$ は捨て, 次の 溶出液 $40 \mathrm{ml}$ を分取], 溶媒留去

$\mathrm{GC}\left[\mathrm{FPD}, 10 \% \mathrm{OV}-225,190 \sim 210^{\circ} \mathrm{C}, 2\right.$ 分 (トリブ チルシクロヘキシルスタナン), 4 分 (ジブチルジシク ロヘキシルスタナン), 8 分 (ブチルトリシクロヘキシ ルスタナン), 拈の打の $0.2 \mathrm{ng}$ ]

$\mathrm{B}$ 法（茶（まっ茶を除く））

試料 $9 \mathrm{~g}, 100^{\circ} \mathrm{C}$ の水 $540 \mathrm{ml}$ で抽出

$360 \mathrm{ml}$ を分取, 臭化水素酸 $20 \mathrm{ml}$ を加え 20 分間放置, トロポロン $0.05 \%$ を含むエチルエーテル $100 \mathrm{ml}+\simeq$ チルエーテル $100 \mathrm{ml}$ で抽出, 脱水, 溶媒留去

$$
\downarrow
$$

$\mathrm{A}$ 法の*以下の操作を行なら.

シヘキサチン拈よびその代謝物（酸化シクロヘキシル スズ (ジ体) および酸化水酸化シクロヘキシルスズ (モ ノ体))をブロム化し，次いでブチル化を行ない，それ ぞれ，FPD・GC で定量する方法である，検量線はお のおのの標準品の $1 \mathrm{ppm}$ 溶液（モノ体はメタノール, 他はアセトン) 0.5 10 ml を混合し, 試料と同様の操 作 (CC を除く)を行ない作成する.

検量線によりシヘキサチン; 酸化ジシクロヘキシルス ズ扣よび酸化水酸化シクロヘキシルスズの重量を求 め, シへキサチンの重量の值と酸化ジシクロヘキシル スズおよび酸化水酸化シクロヘキシルスズの重量の值
にそれぞれ係数 1.28 および 1.64 を乗じてシへキサチ ンに換算したものとを和し，シヘキサチンの重量とす る.

(18) トリアジメホン $(59.10 .31)$

1-(4-クロロフェノキシ)-3, 3-ジメチル-1-(1, 2, 4-ト リアゾール-1-イル)-2-ブタノン

\section{A法（麦・雑穀）}

試料 $20 \mathrm{~g}$ ，アセトン $150 \mathrm{ml}+100 \mathrm{ml}$ で抽出

$$
\downarrow
$$

$50 \mathrm{ml}$ に濃縮， $5 \%$ 塩化ナトリウム $200 \mathrm{ml}$ を加え，ジ クロロメタン $100 \mathrm{ml} \times 2$ で抽出, 脱水, 溶媒留去

\section{$\downarrow$}

残留物をへキサンーアセトニトリル分配, 溶媒留去, 酢酸エチルーヘキサン (5: 95) $10 \mathrm{ml}$ に溶解

$$
\downarrow
$$

* CC〔 $1.5 \mathrm{~cm}$ ，フロリジル $10 \mathrm{~g}$ ，〈酢酸エチルーヘキサ ン $(5: 95) 100 \mathrm{ml}$, 酢酸エチルーヘキサン $(15: 85) 150$ $\mathrm{ml}$ (トリアジメホン用), 酢酸エチルーヘキサン (30: 70) $150 \mathrm{ml}$ (トリアジメホン代謝物用)]

$\downarrow$

GC [FTD, N.P-FID, $5 \%$ OV-101, $180 \sim 220^{\circ} \mathrm{C}$, 2 3 分, $0.4 \mathrm{ng}$, アセトン $8 \mathrm{ml}$ (トリアジメホン), 3〜 4 分, $0.4 \mathrm{ng}$, アセトン $4 \mathrm{ml}$ (トリアジメホン代 謝物) **]

B法（果実，野菜，いも類，さとうきび）

検体 $20 \mathrm{~g}$ 相当の試料, アセトン $100 \mathrm{ml}+50 \mathrm{ml}$ で抽出 $\downarrow$

$20 \mathrm{ml}$ に濃縮， $5 \%$ 塩化ナトリウム $200 \mathrm{ml}$ を加え, ジ クロロメタン $100 \mathrm{ml} \times 2$ で抽出, 脱水, 溶媒留去

$$
\downarrow
$$

アセトン $5 \mathrm{ml}$ に溶解, 凝固液処理, ジクロロメタン $50 \mathrm{ml} \times 2$ で抽出, 脱水, 溶媒留去$$
\downarrow
$$

酢酸エチルーヘキサン (5：95) $10 \mathrm{ml}$ に溶解したのち, $\mathrm{A}$ 法の*以下の操作を行なう.

トリアジメホン扎よ゙その代謝物をそれぞれ N.PFID.GC により定量する方法である，検量線はおの 沶のの標準品を用いて作成する.

検量線より求めたトリアジメホンの重量の值とトリア ジメホン代謝物の重量の值に換算係数 0.99 を乗じて トリアジメホンに換算したものとを和し，トリアジメ ホンの重量とする.

**1- (4-クロロフェノキシ) -3, 3-ジメチル-1- (1,2,4-ト

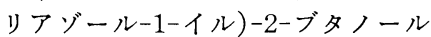

(19) ペンディメタリン (59.10.31)

N-(1-エチルプロピル)-3, 4-ジメチル-2, 6-ジニトロ アニリン

$\mathrm{A}$ 法（麦・雑穀, 豆類)

試料 $20 \mathrm{~g} ，$ アセトン $100 \mathrm{ml}+50 \mathrm{ml}$ で抽出

$50 \mathrm{ml}$ に濃縮, $5 \%$ 塩化ナトリウム $200 \mathrm{ml}$ を加え, 一 キサン $100 \mathrm{ml} \times 2$ で抽出, 脱水, 溶媒留去 


\section{$\downarrow$}

残留物をへキサンーアセトニトリル分配, 溶媒留去, ヘキサン $10 \mathrm{ml}$ に溶解

\section{$\downarrow$}

* CC〔 $[1.5 \mathrm{~cm}, 5 \mathrm{w} / \mathrm{w} \%$ 含水フロリジル $10 \mathrm{~g}$, 〈へキサ ン $100 \mathrm{ml}\rangle$, エチルエーテルーヘキサン(5:95) $100 \mathrm{ml}$ ] $\downarrow$

GC [FTD, N.P-FID, $5 \% \mathrm{OV}-17, \quad 180 \sim 200^{\circ} \mathrm{C}, 4$ 分, $0.08 \mathrm{ng}$, ヘキサン $20 \mathrm{ml}$ ]

$\mathrm{B}$ 法（野菜, い夕類)

検体 $20 \mathrm{~g}$ 相当の試料，アセトン $100 \mathrm{ml}+50 \mathrm{ml}$ で抽 出

$20 \mathrm{ml}$ に濃縮， $5 \%$ 塩化ナトリウム $200 \mathrm{ml}$ を加光， 、 キサン $100 \mathrm{ml} \times 2$ で抽出, 脱水, 溶媒留去

\section{$\downarrow$}

ヘキサン $10 \mathrm{ml}$ に溶解したのち，A法の*以下の操作 を行なう。

(20) ホセチル (59.10.31)

アルミニウム トリス（エチルホスホナート）

検体 $25 \mathrm{~g}$ 相当の試料, 蒸留水 $100 \mathrm{ml}+50 \mathrm{ml}$ で抽出 (30 分間振とら後, 毎分 2000 回転で 20 分間遠心分離 し, 上澄み部分をろ過), 蒸留水を加光 $300 \mathrm{ml}$ とす る.

$$
\downarrow
$$

$\mathrm{CC}\lceil 1.5 \mathrm{~cm}$, 陰イオン交換樹脂(Dowex SAR, OH 型) $10 \mathrm{ml}, 0.2 \mathrm{~N}$ 水酸化バリウム溶液を $40 \mathrm{ml} / l$ の割合で 加えて炭酸を除去した $1 \mathrm{~N}$ 水酸化ナトリウム溶液 200 $\mathrm{ml}$ および蒸留水 $300 \mathrm{ml}$ で樹脂を洗浄, 抽出液を流速 6 7 ml/分 で流す. 次いで蒸留水 $200 \mathrm{ml}$ で樹脂を洗 浄, 次いで $0.2 \mathrm{~N}$ 水酸化バリウム溶液を $20 \mathrm{ml} / l$ の割 合で加えて炭酸を除去した $0.5 \mathrm{~N}$ 水酸化ナトリウム溶 液 $200 \mathrm{ml}$ を流速 6 ～ $7 \mathrm{ml} /$ 分 で流し入れ溶出させる】

$$
\downarrow
$$

これに，あらかじめ水素型にして 2 倍容量の蒸留水を 加えて 15 分間かくはんして洗浄した陽イオン交換樹 脂(Dowex HCR-W2) を加光，pH を〜 7 に調整し， 吸引ろ過する. 蒸留水で洗浄し, 洗液をろ液に合わせ, 蒸留水を加えて $300 \mathrm{ml}$ とする.

$$
\downarrow
$$

$30 \mathrm{ml}$ を分取, $0.01 \mathrm{M}$ シュウ酸ナトリウム溶液 $5 \mathrm{ml}$ を加え, $50^{\circ} \mathrm{C}$ 以下で $5 \mathrm{ml}$ に濃縮

$$
\downarrow
$$

CC〔 $1.5 \mathrm{~cm}$ ，陽イオン交換樹脂 (ムロマック AG50W $\mathrm{X} 8, \mathrm{H}^{+}$型) $2 \mathrm{ml}$, 蒸留水 $50 \mathrm{ml}$ で樹脂を洗浄, 濃縮 液を流速 $0.3 \sim 0.4 \mathrm{ml} /$ 分で流し入れ，次いで蒸留水を 同流速で流し入れ，溶出液 $10 \mathrm{ml}$ をとる]
溶出液の $1 \mathrm{ml}$ をメチル化装置の反応管に分取, イソ プロピルアルコール $5 \mathrm{ml}$ を加え, ジアゾメタンが過 剩になり, 微黄色を呈するまでジアゾメタンを通気し たのち，25 30 $\mathrm{C}$ で 15 分間放置, 窒素ガスを穏やか に通して過剰のジアゾメタンを除去したのち，イソプ ロピルアルコールで $10 \mathrm{ml}$ とする.

GC $〔 \mathrm{FPD}(\mathrm{P}), 10 \% \mathrm{PEG} 20 \mathrm{~m}$ : テレフタル酸 $(1: 1)$, $150 \sim 170^{\circ} \mathrm{C}, 2.5$ 分 (ホスホン酸エチルメチル), 2 分 (ホスホン酸ジメチル), おの打の $0.1 \mathrm{ng}$, イソプロピ ルアルコール $10 \mathrm{ml}$ ]

ホセチルおよびその代謝物をメチル化してそれぞれ FPD.GC で定量する方法である. 検量線はホセチル およびホスホン酸の標準品の $25 \mathrm{ppm}$ 溶液 $1 \sim 20 \mathrm{ml}$ ずつを混じ，水で $300 \mathrm{ml}$ としたものについて試料と まったく同様の操作を行ない作成する.

検量線よりホセチルおよびホスホン酸の重量を求め る. ホセチルの重量の值とホスホン酸の重量に換算係 数 4.32 を乗じてホセチルの重量に換算したものとを 和しホセチルの重量とする.

(21) フェンバレレート $(59.10 .31)$

๙-シアノ-3-フェノキシベンジル-2-(4-クロロフェニ ル)-3ーメチルブチラート

検体 $20 \mathrm{~g}$ 相当の試料（なつみかんの外果皮の場合は $5 \mathrm{~g})$, アセトン $150 \mathrm{ml}+100 \mathrm{ml}$ で抽出

$50 \mathrm{ml}$ に濃縮, $5 \%$ 塩化ナトリウム $200 \mathrm{ml}$ を加え, へ キサン $100 \mathrm{ml} \times 2$ で抽出, 脱水, 溶媒留去

残留物をへキサンーアセトニトリル分配, 溶媒留去, エ チルエーテルーヘキサン (15:85) $10 \mathrm{ml}$ に溶解

$\mathrm{CC}[1.5 \mathrm{~cm}$ ，フロリジル $10 \mathrm{~g}$, 〈エチルエーテルーヘキ サン $(15: 85) 50 \mathrm{ml}\rangle$, エチルエーテルーヘキサン $(30$ :

70) $100 \mathrm{ml}$ ], 溶媒留去

$\mathrm{GC}\left[\mathrm{ECD}, 5 \% \mathrm{OV}-17,270 \sim 280^{\circ} \mathrm{C}, 4\right.$ 分, $0.04 \mathrm{ng}$, アセトン $2 \mathrm{ml}$ ]

\section{引用 文 献}

1） 後藤真康：農薬誌 3,169 (1978)

2) 後藤真康：農薬誌 3,315 (1978)

3) 後藤真康：農薬誌 4, 219 (1979)

4）加藤正男 - 岩永恵夫：農薬誌 5 , 271 (1980)

5) 阪本 剛 - 大井明大：農薬誌 9, 159 (1984)

6）後藤真康・加藤誠哉：残留農薬分析法, ソフトサ イエンス社, 1970 